\title{
Heart size and mean muscle fibre cross-sectional area related to birth weight in pigs
}

\author{
Marita Ruusunen, Eero Puolanne \\ Department of Food Technology, University of Helsinki, PO Box 66, FI-00014 Helsinki, Finland, \\ e-mail: marita.ruusunen@helsinki.fi \\ Kirsi Partanen \\ MTT Agrifood Research Finland, Animal Production Research, Tervamäentie 179, \\ FI-05840 Hyvinkä̈̈, Finland
}

\begin{abstract}
One of the aims in domestic pig breeding has been to increase the size of litters resulting in variation in birth weight of piglets. Pig breeding has also resulted in increased body muscle mass. Muscles with the same size can consist either of large number of thin muscle fibres or small number of thick muscle fibres. Larger body muscle content means that in living animal the heart must pump blood to larger muscle mass than earlier. Our interest in this study was to investigate the relationship between the pig's birth weight and (i) growth performance and carcass composition, (ii) the size of organs, and (iii) the mean muscle fibre cross-sectional area at slaughter. The study consisted of twenty pigs slaughtered at the age of $165 \pm 2$ days. The day after the slaughter, the carcass composition was determined by dissecting the chilled carcass into lean, fat, bones, and skin and organs were weighed. The average cross sectional area of muscle fibres was determined from three fast-twitch muscles longissimus dorsi, semimembranosus, gluteus superficialis, and two slow-twitch muscles infraspinatus and masseter. The birth weight of pigs ranged from 0.9 to $2.2 \mathrm{~kg}$. We found no clear relationships between the birth weight and the pig's growth performance from birth to slaughter. When the birth weight increased the heart weight at slaughter increased as well $(\mathrm{P}<0.01)$. The heart weight was higher in those pigs with high carcass weight $(\mathrm{P}<0.05)$ and with the high weight of total muscle mass in the carcass $(\mathrm{P}<0.001)$. The cross sectional area of muscle fibres in $M$. longissimus dorsi $(\mathrm{P}<0.05)$, M. semimembranosus $(\mathrm{P}<0.10)$, and M. gluteus superficialis $(\mathrm{P}<0.05)$ was larger in those pigs with low birth weight compared to those found in pigs with high birth weight.
\end{abstract}

Key-words: Pig, birth weight, heart, fast-twitch muscle, slow-twitch muscle, muscle fibre 
Ruusunen, M. et al. Heart size and muscle fibre thickness related to birth weight in pigs

\section{Introduction}

The birth weight of a domestic pig is about 1.5 $\mathrm{kg}$, but can range enormously from about $0.5 \mathrm{~kg}$ to about $2.5 \mathrm{~kg}$. The variation in the birth weight is large both within and between different litters, and low-birth-weight piglets are generally born in large litters and in litters of primiparous and old ( $>$ $5^{\text {th }}$ parity) sows (Milligan et al. 2002). Low birth weight is associated with reduced piglet survival and postnatal growth rate (Dwyer et al. 1993, Milligan et al. 2002), but can also influence carcass composition and muscle characteristics at slaughter (Powell and Aberle 1980, Kühn et al. 2002, Gondret et al. 2005 and 2006).

As the pig grows, the weight of its organs increases, but their relative weight as a percentage of body weight declines. At birth, the relative weight of the heart is about one percent of body weight (Pond and Houpt 1978, p. 116), and declines gradually to $0.25-0.3 \%$ when the pig has reached a body weight of 90-105 kg (Priebs and Preetz 1977, Pond and Houpt 1978, p. 116, Yang and Lin 1997). Larger body muscle content means that in living animal the heart must pump blood to larger muscle mass than earlier. In a newborn pig, the relative weights of the liver and the kidneys are $3.1 \%$ and $1.0 \%$, respectively, and in an adult pig, $1.4-1.5 \%$ and $0.3 \%$, respectively (Pond and Houpt 1978, p. 97).

The growth of muscles is of great interest in meat-producing animals because of the commercial importance of muscle mass. As the size of a muscle increases, both the cross-sectional area and the length of muscle fibres increase (Swatland 1976). At birth, the cross-sectional area of different muscle fibre types (I, IIA, and IIB) is about the same (Bader 1983), but at slaughter, the cross-sectional area of type IIB fibres is about twice as large as that of type I and type IIA fibres in the longissimus dorsi muscle (Ruusunen and Puolanne 2004). Although the number of capillaries/fibre increases by age, the capillary density decreases due to muscle fibre hypertrophy (Oksbjerg et al. 1994).

The number of muscle fibres is fixed at birth (Wigmore and Stickland 1983). Muscle growth and ultimate muscle mass are largely determined by the number and the growth of individual muscle fibres. If the number of muscle fibres is low, the thickness of muscle fibres must grow more than when the number of muscle fibres is high in order to attain the same muscle mass at slaughter. Runt pigs have been reported to have a lower total number of muscle fibres already in the uterus than their heavier littermates (Wigmore and Stickland 1983, Handel and Stickland 1987, Kühn et al. 2002). Therefore, for pigs with about the same carcass leanness and live weight at slaughter, the crosssectional area of muscle fibres should be larger in those pigs with low birth weight than in those with high birth weight.

The purpose of this study was to investigate the relationship between the pig's birth weight and (i) growth performance and carcass composition, (ii) the size of heart, liver, and kidneys, and (iii) the mean muscle fibre cross-sectional area at slaughter. This study was a part of a larger research project that studied the effect of growth rate on carcass characteristics, the size of organs, the oxidative and glycolytic properties of slow-twitch and fast-twitch muscles, muscle fibre properties, blood parameters, and meat quality.

\section{Materials and methods}

\section{Animals}

The pigs were raised at MTT Agrifood Research Finland in Hyvinkää. The study consisted of 20 pigs (10 gilts and 10 barrows) from different litters. During the suckling and post-weaning periods, the pigs were housed with their litter mates and received standard pelleted starter and weaner diets, respectively. From a body weight of about $24 \mathrm{~kg}$, the pigs were housed individually in pens of $1.0 \mathrm{~m} \times 2.5 \mathrm{~m}$. They received a diet which consisted of $75.30 \%$ barley, $21.82 \%$ soybean meal, $0.24 \%$ L-lysine $\mathrm{HCl}$, $0.04 \%$ L-threonine, $0.04 \%$ DL-methionine, $1.21 \%$ mineral and vitamin premix, $0.36 \%$ monocalcium phosphate, and $0.99 \%$ limestone. This diet was formulated to meet the nutrient requirements of growing 
Vol. 16 (2007): 259-266

pigs from $25 \mathrm{~kg}$ to $55 \mathrm{~kg}$ body weight (MTT 2004). Feed was given according to a restricted weightbased feeding scale, and the daily allowance was increased weekly from 13 to $30 \mathrm{MJ}$ NE.

\section{Slaughtering, sampling, and muscle fibre analysis}

The pigs were slaughtered at the average age of 165 $\pm 2 \mathrm{~d}$ at the experimental abattoir of the University of Helsinki, Department of Food Technology. Muscle samples for analysing the mean fibre cross-sectional area were collected from $M$. longissimus dorsi, M. semimembranosus, M. gluteus superficialis, M. infraspinatus, and M. masseter from 20 to 40 minutes after the slaughter. The samples were frozen in liquid nitrogen and stored at $-80^{\circ} \mathrm{C}$ until analysed. The cross-sectional area of muscle fibres were measured from sections stained using the myosin ATPase method (Brooke and Kaiser 1970) with an acid preincubation solution ( $\mathrm{pH} 4.6)$. The sections $(14 \mu \mathrm{m})$ were cut at $-24^{\circ} \mathrm{C}$ in a cryostat (Reichert-Jung 2800 E, Germany). Stained sections were examined with an image analysis system using a computer programme (KS300, Carl Zeiss Vision $\mathrm{GmbH}$, Germany). The mean muscle fibre crosssectional area was calculated for different muscles by dividing the whole analysed muscle area by the number of fibres on that area. Always at least 400 muscle fibres were counted.

The day after the slaughter, the carcass composition was determined by dissecting the chilled carcass into lean, fat, bones, and skin, and the heart, liver, and kidneys were weighed.

\section{Statistical analysis}

Partial correlation coefficients were calculated to study the relationships of the birth weight and heart weight at slaughter to the pigs' growth performance, carcass composition, organ weight, and the mean cross-sectional area of muscle fibres in different muscles. The effect of sex was adjusted for. Re- gression analysis was used when testing the effect of birth weight and weight of muscle mass in the carcass on the variation in heart weight. The data was analysed with the SAS programme (SAS ${ }^{\circledR}$ for Windows, Release 8.12).

\section{Results}

\section{Growth performance, carcass composition and organ size}

The birth weight of the pigs was $1.6 \mathrm{~kg}$ (range $0.9-2.2 \mathrm{~kg}$ ) (Table 1). The birth weight of six pigs ranged from 0.9 to $1.3 \mathrm{~kg}$, that of eight pigs from 1.4 to $1.7 \mathrm{~kg}$, and that of six pigs from 1.8 to $2.2 \mathrm{~kg}$. At the slaughter-age of 165 days, the pigs weighed

Table 1. Birth weight, live weight, and carcass weight of pigs as well as organ weights, carcass composition and mean muscle fibre cross-sectional area at slaughter $(\mathrm{N}=20$ pigs $)$.

\begin{tabular}{ll}
\hline & Mean \pm s.d. \\
\hline Birth weight, kg & $1.6 \pm 0.3$ \\
Live weight at slaughter, kg & $107.6 \pm 6.8$ \\
Weight gain, g d ${ }^{-1}$ & \\
$\quad$ Suckling period & $257 \pm 40$ \\
$\quad$ Post-weaning period & $201 \pm 37$ \\
$\quad$ Fattening period & $891 \pm 57$ \\
$\quad$ From birth to slaughter & $642 \pm 40$ \\
Carcass weight, kg & $85.5 \pm 5.5$ \\
Muscle mass, kg & $51.0 \pm 2.7$ \\
Fat, kg & $11.6 \pm 2.9$ \\
Heart, g & $350 \pm 24$ \\
Liver, g & $1621 \pm 188$ \\
Kidneys, g & $368 \pm 42$ \\
Cross-sectional area of muscle fibres, & \\
x10 ${ }^{3} \mu m^{2}$ & \\
M. longissimus dorsi & \\
M. semimbranosus & $5.8 \pm 0.9$ \\
M. gluteus superficialis & $5.9 \pm 0.7$ \\
M. infraspinatus & $5.7 \pm 1.1$ \\
M. masseter & $5.2 \pm 0.8$ \\
\hline
\end{tabular}


Ruusunen, M. et al. Heart size and muscle fibre thickness related to birth weight in pigs

$107.6 \mathrm{~kg}$ (range $92.5-118.5 \mathrm{~kg}$ ) and their carcass weight was $85.5 \mathrm{~kg}$ (range $70.8-92.5 \mathrm{~kg}$ ). There were no significant correlations between the birth weight and the growth rate of pigs in any stages of growth from birth to slaughter. The lean meat and fat content of carcasses averaged $62.9 \pm 2.4 \%$ and $14.2 \pm 3.0 \%$, respectively, corresponding to a total muscle mass of about $51.0 \pm 2.7 \mathrm{~kg}$, and about 11.6 $\pm 2.9 \mathrm{~kg}$ of fat in the carcass. There was no significant relationship between the pigs' birth weight and carcass composition at slaughter.

The average weight of the hearts was $350 \pm 24$ $\mathrm{g}$ (range from 305 to $395 \mathrm{~g}$ ), and its relative average weight was $0.33 \pm 0.02 \%$ (range from 0.29 to $0.36 \%$ ) of body weight. There was a positive correlation between the birth weight and the heart weight of pigs at slaughter $(r=0.591, \mathrm{P}<0.01)$, between the carcass weight and the heart weight $(\mathrm{r}=0.538, \mathrm{P}<0.05)$, and between the weight of total muscle mass and the heart weight $(\mathrm{r}=0.778$, $\mathrm{P}<0.001$ ) (Table 2). The weight of total muscle mass explained $61 \%$ of the variation in the heart weight, and the birth weight explained $36 \%$ of this variation. Including both the muscle mass and the birth weight in the regression model $75 \%$ of the variation in the heart weight was explained.

The average weight of the livers was $1621 \pm$ $188 \mathrm{~g}$ (range from 1208 to $1939 \mathrm{~g}$ ), and that of the kidneys $368 \pm 42 \mathrm{~g}$ (range from 300 to $452 \mathrm{~g}$ ), and their relative weights averaged $1.5 \pm 0.2 \%$ and $0.34 \pm 0.04 \%$ of total body weight, respectively. The weights of neither the liver nor kidneys significantly correlated with the birth weight.

\section{Muscle fibres}

The mean muscle fibre cross-sectional area was larger in the fast-twitch than in the slow-twitch muscles (Table 1). In the fast-twitch muscles, the largest mean muscle fibre cross-sectional area was

Table 2. Partial correlation coefficients between both the birth weight and heart weight at slaughter, and the weight gain, carcass composition, organ weight, and the cross-sectional area of muscle fibres.

\begin{tabular}{|c|c|c|}
\hline & Birth weight & Heart weight \\
\hline Body weight at slaughter & 0.068 & 0.387 \\
\hline Carcass weight & 0.234 & $0.538^{*}$ \\
\hline \multicolumn{3}{|l|}{ Weight gain } \\
\hline Suckling period & 0.377 & 0.074 \\
\hline Post-weaning period & -0.375 & -0.115 \\
\hline Fattening period & -0.306 & 0.153 \\
\hline From birth to slaughter & 0.006 & 0.365 \\
\hline Muscle mass & 0.282 & $0.778^{* * *}$ \\
\hline Fat weight & -0.093 & -0.020 \\
\hline Lean meat percentage & 0.224 & 0.237 \\
\hline Fat percentage & -0.143 & -0.164 \\
\hline Heart weight & $0.591^{* *}$ & \\
\hline Liver weight & -0.135 & -0.135 \\
\hline Kidney weight & -0.127 & $0.402^{\circ}$ \\
\hline \multicolumn{3}{|c|}{ Cross-sectional area of muscle fibres } \\
\hline M. longissimus dorsi & $-0.483^{*}$ & -0.283 \\
\hline M. semimembranosus & $-0.397^{\circ}$ & $-0.509^{*}$ \\
\hline M. gluteus superficialis & $-0.477^{*}$ & $-0.419^{\circ}$ \\
\hline M. infraspinatus & -0.061 & 0.265 \\
\hline M. masseter & 0.111 & 0.047 \\
\hline
\end{tabular}


Vol. 16 (2007): 259-266

found in M. semimebranosus, followed by $M$. longissimus dorsi and M. gluteus superficialis. In the slow-twitch muscles, the cross-sectional area of muscle fibres was considerably larger in the $M$. infraspinatus than in the M. masseter. There was a negative correlation between the birth weight and the mean muscle fibre cross-sectional area in the fast-twitch muscles longissimus dorsi $(\mathrm{r}=-0.483$, $\mathrm{P}<0.05)$, semimembranosus $(\mathrm{r}=-0.397, \mathrm{P}<0.10)$ and gluteus superficialis $(\mathrm{r}=-0.477, \mathrm{P}<0.05)$ (Table 2). In slow-twitch muscles, however, we found no significant relationships between the birth weight and the mean cross-sectional area of muscle fibres. There was, however, a negative correlation between the mean cross-sectional area of muscle fibres in M. longissimus dorsi and the growth rate of pigs during the suckling period $(\mathrm{r}=-0.667, \mathrm{P}<0.01)$. The mean muscle fibre cross-sectional area showed no correlation with carcass composition.

\section{Discussion}

The birth weight of piglets varies considerably within the litter, and is related to the size of the litter. Low birth weight and high birth weight variation are the major contributors to poor pre-weaning survival and growth rate (Milligan et al. 2002). Several reports have indicated that low-birth-weight piglets gain weight more slowly, particularly during the suckling and post-weaning periods, and consequently reach similar slaughter weights at an older age than do piglets with a heavier birth weight (Nissen et al. 2004, Gondret et al. 2005 and 2006). In this study, however, we found no clear relationship between the birth weight and the growth rate of pigs in different stages of growth from birth to slaughter, nor did the birth weight correlate with the carcass composition. Similarly, Nissen et al. (2004) and Gondret et al. (2005) found no significant differences in carcass lean meat content at slaughter in relation to birth weight. However, some reports have shown that low-birth-weight piglets had more fat in their carcass at slaughter (Gondret et al. 2006) or as adults (Poore and Fowden 2004) than did the heavy-birth-weight piglets.

The size of the heart in the domestic pig has increased with the selection for higher weight gain and leaner carcasses (Cliplef and McKay 1993, Yang and Lin 1997), but the heart size may not have been able to keep pace with the development of muscle growth (Yang and Lin 1997, Petrási et al. 2003). In this study, the heart size averaged 350 $\mathrm{g}$ and constituted $0.33 \%$ of body weight. This is in accordance with earlier reports in which the relative heart weight of slaughtered pigs has ranged from $0.34 \%$ to $0.41 \%$ of body weight (Cliplef and McKay 1993, Yang and Lin 1997). We found a positive correlation between the birth weight and the heart weight at slaughter. A part of this did likely result from differences in body weight at slaughter, as the pigs were slaughtered at the same age and the heart weight correlated positively with the carcass weight $(\mathrm{r}=0.538, \mathrm{P}<0.05)$ similarly as Oksbjerg et al. (2000) have also shown.

The function of the heart is to pump blood to the muscles, and the heart weight of slaughtered pigs has been shown to correlate with the protein content and protein gain in the carcass (Davey and Bereskin 1978). We also found a positive correlation between the heart weight and the weight of muscles at slaughter $(\mathrm{r}=0.778, \mathrm{P}<0.001)$. Yang and Lin (1997) reported that the heart weight correlated negatively with backfat thickness. In the present study, the muscle weight at slaughter explained $61 \%$ of the variation in the heart weight. Our results seem to indicate that increased muscle growth puts pressure on the heart to pump more blood into the muscles, thus resulting in the enlargement of heart size. Poore et al. (2002) reported that small birth weight correlated negatively with blood pressure in the later life of the pigs, which could contribute to the development to cardiovascular diseases.

The heart rate increases very easily in pigs which weakens the function of the heart in stressful situations. Fattening pigs exercise little during their life in the piggery, and heart size seldom becomes a limiting factor. However, in transport to the slaughterhouse and during slaughter, the pigs are subjected to great stress. The strength of the heart and the oxidative capacity of muscles are important 


\section{AGRICULTURAL AND FOOD SCIENCE}

Ruusunen, M. et al. Heart size and muscle fibre thickness related to birth weight in pigs

in stressful situations to guarantee that the muscles receive enough oxygen. In very stressful situations, the limited heart capacity of lean pigs may result in the sudden death of the pigs (Petrási et al. 2003). Whether the size of the heart has grown in relation to body mass and to muscle mass under selection for leanness and fast growth of pigs remains unknown. One could, however, suppose that a large and strong heart will improve the stress resistance of the pigs.

As a pig grows, so does the size of the liver and the kidneys, but the size of the kidneys increases more than does that of the heart. In this study, neither the liver nor the kidney weight of slaughtered pigs correlated with the birth weight $(\mathrm{P}>0.05)$. Several reports have shown that increasing dietary protein and amino acid supply or both increases the weight of both the liver and the kidney, but do not affect the size of the heart (Chen et al. 1999, Chiba et al. 2002, Szabó et al. 2001, Ruusunen et al. 2007). This is due to the role of the liver and the kidneys in protein metabolism. One has to consider that in the present study the feeding was restricted and the pigs were slaughtered at a constant age. The results may be different with ad lib feeding and in that case when the pigs are slaughtered at a constant live weight.

Breeding has resulted in leaner carcasses, although whether the carcass leanness has been achieved by a large number of thin muscle fibres or by a small number of thick muscle fibres remains unknown. In Denmark, Oksbjerg et al. (2000) studied changes occurred in the muscle fibre composition of Landrace pigs between the years 1976 and 1995. They found that the pigs of 1995 had higher daily weight gain and carcass lean percentage than did the pigs of 1976 . However, the mean fibre crosssectional area was smaller in the pigs of 1995, indicating a higher number of muscle fibres than in the pigs of 1976. In this study, low piglet birth weight led to a larger mean fibre cross-sectional area in fast-twitch muscles at the slaughter age of 165 days. Several other studies have also shown that piglet birth weight correlates negatively with muscle fibre thickness in M. longissimus dorsi (Bee 2004, Gondret et al. 2005), in M. semitendinosus (Hegarty and Allen 1978, Powell and Aberle 1981, Handel and Stickland 1987, Bee 2004, Gondret et al. 2005), in M. psoas major and in M. semimembranosus (Powell and Aberle 1981, Hegarty and Allen 1978). In our study, the birth weight of pigs did not correlate with the muscle fibre cross-sectional area in slow-twitch muscles, whereas Handel and Stickland (1987) reported a larger muscle fibre cross-sectional area in the slow-twitch muscle $M$. trapezius in runt littermates. Gondret et al. (2005) found a similar phenomenon in slow-twitch muscle M. rhomboideus.

Hegarty and Allen (1978), Powell and Aberle (1981), and Kühn et al. (2002) reported from indirect measurements that smaller pigs have fewer muscle fibres at birth. Hegarty and Allen (1978) and Rehfeldt et al. (2000) pointed out that the postnatal hypertrophy of individual muscle fibres is higher when the muscle contains fewer muscle fibres in the muscle. These findings are in line with the negative correlations found between the birth weight and the cross-sectional area of muscle fibres in the fast-twitch muscles in this study. In contrast, in pigs selected at a fixed slaughter age, small littermates had smaller muscle fibres in M. semitendinosus compared to middle weight and heavy weight littermates (Nissen et al. 2004), i.e. the growth rate of fibres in small-birth weight may be slower than in larger birth-weight. Nissen et al. (2004) had taken the samples both in red and white part of M. semitendinosus. In the present study birth weight effected on muscle fibre cross sectional area in fast-twitch muscles but not in slow-twitch muscles.

\section{Conclusions}

The heart size of the pig at slaughter is related to its birth weight, carcass weight, and the amount of muscle mass in the carcass. Muscle fibres are thicker in $M$. longissimus dorsi, M. semimembranosus, $M$. gluteus superficialis, and $M$. infraspinatus than in $M$. masseter. In pigs with low birth weight, the crosssectional area of muscle fibres in fast-twitch muscles at slaughter is larger than in pigs with high birth weight, when the pigs are slaughtered in the same age. In slow-twitch muscles this is not found. 


\title{
AGRICULTURAL AND FOOD SCIENCE
}

\author{
Vol. 16 (2007): 259-266
}

Acknowledgements. This study was funded by the Finnish ministry of Agriculture and Forestry, the meat industry, and the Finnish Animal Breeding Association.

\section{References}

Bader, R. 1983. Vergleichende histometrische und histologische Untersuchungen an der Skelettmusculatur von Wild- und Hausschweinen. Berlin, München, Tierärztliche Wochenschrift 96: 89-97.

Bee, G. 2004. Effect of early gestation feeding, birth weight, and gender of progeny on muscle fiber characteristics of pigs at slaughter. Journal of Animal Science 82: $826-836$.

Brooke, M.H. \& Kaiser, K.K. 1970. Muscle fiber types: How many and what kind. Archiv für Neurology 123: 369-379.

Chen, H.-Y., Lewis, A.J., Miller, P.S. \& Yen, J.Y. 1999. The effect of excess protein on growth performance and protein metabolism of finishing barrows and gilts. Journal of Animal Science 77: 3238-3247.

Chiba, L.I., Kuhlers, D.L., Frobish, L.T., Jungst, S.B., HuffLonergan, E.J., Lonergan, S.M. \& Cummins, K.A. 2002. Effect of dietary restrictions on growth performance and carcass quality of pigs selected for lean growth efficiency. Livestock Production Science 74: 93-102.

Cliplef, R.L. \& McKay, R.M. 1993. Visceral organ weights of swine selected for reduced backfat thickness and increased growth rate. Canadian Journal of Animal Science 73: 201-206.

Davey, R.J. \& Bereskin, B. 1978. Genetic and nutritional effects on carcass composition and organ weights of market swine. Journal of Animal Science 46: 992-1000.

Dwyer, C.M., Fletcher, J.M. \& Stickland, N.C. 1993. Muscle cellularity and postnatal growth in the pig. Journal of Animal Science 71: 3339-3343.

Gondret, F., Lefaucheur, L., Juin, H., Louveau, I. \& Lebret, B. 2006. Low birth weight is associated with enlarged muscle fiber area and impaires meat tenderness of the longissimus muscle in pigs. Journal of Animal Science 84: 93-103.

Gondret, F., Lefaucheur, L., Louveau, I., Lebret, B., Pichodo, X. \& Le Cozler, Y. 2005. Influence of piglet birth weight on postnatal growth performance, tissue lipogenic capacity and muscle histological traits at market weight. Livestock Production Science 93: 137-146.

Handel, S.E. \& Stickland, N.C. 1987. Muscle cellularity and birth weight. Animal Production 44: 311-317.

Hegarty, P.V.J. \& Allen, C.E. 1978. Effect of prenatal runting on postnatal development of skeletal muscles in swine and rats. Journal of Animal Science 46: 1634-1640.

Kühn, G., Rehfeldt, C., Hartung, M. \& Ender, K. 2002. Eine bessere Schlachtkörperqualität durch schwerere Ferkel. Heavy newborn piglets develop a high carcass quality. Fleischwirtschaft 82: 128-129.

Milligan, B.N., Fraser, D. \& Kramer, D.L. 2002. Within-litter birth weight variation in the domestic pig and its relation to pre-weaning survival, weight gain, and variation in wean- ing weights. Livestock Production Science 76: 181-191.

MTT 2004. Feed tables and feeding recommendations 2004: ruminants - pigs - poultry - fur animals - horses (in Finnish). Agrifood Research Working papers 86. Available on internet: www.mtt.fi/mtts/pdf/mtts86.pdf.

Nissen, P.M., Jorgensen, P.F. \& Oksbjerg, N. 2004. Within-litter variation in muscle fiber characteristics, pig performance, and meat quality traits. Journal of Animal Science 82: 414-421.

Oksbjerg, N., Petersen, J.S., Sorensen, I.L., Henckel, P., Vestergaard, M., Ertbjerg, P., Moller, A.J., Bejerholm, C. and Stoier, S. 2000. Long-term changes in performance and meat quality of Danish Landrace pigs: a study on a current compared with an unimproved genotype. Animal Science 71: 81-92.

Oksbjerg, N., Rolph, T. \& Henckel, P. 1994. Effects of salbutamol, a $\beta_{2}$-adrenergic agonist, on muscles of growing pigs fed different levels of dietary protein. I. Muscle fibre properties and muscle protein accretion. Acta Agriculturae Scandinavica, Section A, Animal Science 44: 12-19.

Petrási, Z., Romvári, R., Bajzik, G., Repa, I. \& Horn, P. 2003. Examination of the heart capacity of meat- and fat-type pigs by means of EcG-gated dynamic magnetic resonance imaging and computerized tomography. Livestock Production Science 83: 113-120.

Pond, W.G. \& Houpt, K.A. 1978. The biology of the pig. Cornell University Press Ltd., 2-4 Brook Street, London W1Y 1AA. 371 p. pp. 97, 116.

Poore, K.R. \& Fowden, A.L. 2004. The effects of birth weight and postnatal growth patterns on fat dept and plasma leptin concentrations in juvenile and adult pigs. Journal of Physiology 558: 295-304.

Powell, S.E. \& Aberle, E.D. 1980. Effects of birth weight on growth and carcass composition of swine. Journal of Animal Science 50: 860-868.

Powell, S.E. \& Aberle, E.D. 1981. Skeletal muscle and adipose tissue cellularity in runt and normal birth weight swine. Journal of Animal Science 52: 748-756.

Priebs, G. \& Preetz, G. 1977. Die Herzmasse - ein Selektionskriterium für die Beschaffenheit von Schweinefleisch. Fleish 31: 98.

Rehfeldt, C., Fiedler, I, Dietl, G. \& Ender, K. 2000. Myogenesis and postnatal skeletal muscle cell growth as influenced by selection. Livestock Production Science 66: 177-188.

Ruusunen, M., Partanen, K., Pösö, R. \& Puolanne, E. 2007. The effect of dietary protein supply carcass composition, size of organs, muscle properties and meat quality of pigs. Livestock Science 107: 170-181.

Ruusunen, M. \& Puolanne, E. 2004. Histochemical properties of fibre types in muscles of wild and domestic pigs and the effect of growth rate on muscle fibre properties. Meat Science 67: 533-539.

Swatland, H.J. 1976. Longitudinal fascicular growth in the porcine longissimus muscle. Journal of Animal Science 42: 63-66.

Wigmore, P.M.C. \& Stickland, N.C. 1983. Muscle development in large and small pig fetuses. Journal of Anatomy 137: 235-245

Yang, T.S. \& Lin, J.H. 1997. Variation of heart size and its correlation with growth performance and vascular space in domestic pigs. Animal Science 64: 523-528. 


\section{SELOSTUS}

\section{Sian syntymäpainon vaikutus sydämen kokoon ja lihassolujen paksuuteen teurasiässä \\ Marita Ruusunen, Eero Puolanne, Kirsi Partanen \\ Helsingin yliopisto ja Maa-ja elintarviketalouden tutkimuskeskus}

Tutkimuksessa selvitettiin sikojen syntymäpainon yhteyttä niiden (i) kasvuun ja ruhon koostumukseen, (ii) elinten painoon ja (iii) lihassolujen paksuuteen teurasiässä. Tutkimus toteutettiin siten, että kaksikymmentä syntymäpainoltaan keskimäärin 1,6 kg:n painoista sikaa teurastettiin 165:n \pm 2 päivän ikäisinä. Sikojen elopaino oli teurastettaessa keskimäärin $107,6 \mathrm{~kg}$ ja ruhopaino $85,5 \mathrm{~kg}$. Vuorokausi teurastuksen jälkeen jäähdytetyt ruhot leikattiin ja lihat, rasvat, sydän, maksa ja munuaiset punnittiin. Lihassolujen poikkipinta-ala mitattiin kolmesta vaaleasta ja kahdesta tummasta lihaksesta. Vaaleat lihakset olivat longissimus dorsi, semimembranosus ja gluteus superficialis ja tummat lihakset infraspinatus ja masseter. Tutkimuksessa syntymäpainolla ei havaittu olevan selkeää yhteyttä sian kasvuun eikä ruhon koostumukseen. Mitä painavampi eläin oli syntyessään, sitä suurempi oli sen sydän teurasiässä. Lihasmassan kasvaessa myös sydämen koko kasvoi. Maksan ja munuaisten painoon syntymäpaino ei vaikuttanut. Vaaleissa lihaksissa syntymäpainon ja lihassolujen keskimääräisen poikkipinta-alan välillä oli negatiivinen korrelaatio, eli samanikäisissä sioissa lihassolut olivat paksumpia syntymäpainoltaan pienemmillä kuin suuremmilla sioilla. Tummissa lihaksissa vastaavaa ei todettu. 